\title{
Financial Reporting And Tax Issues At JC Construction Corporation: An Instructional Case
}

Jane E. Baird, Minnesota State University, Mankato

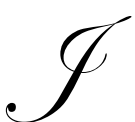

C Construction Corporation (JCCC) is a privately held corporation with 10 shareholders, who are all members of the Carpenter family. The company was founded by Joe Carpenter in the late 1990s. The company's projects involve mostly comparatively small commercial building construction, such as restaurants and smaller-scale stores. JCCC specializes in renovation and restoration projects rather than new construction, but does occasionally take on some new construction projects. The company does not build or renovate single family homes. JCCC is located in Minnesota, near the Minneapolis/St. Paul area where remodeling contractors are in high demand.

Despite a slow down in real estate sales and construction in the area, the company has experienced substantial growth and has more opportunities for contracts than it is currently able to handle. The family feels that its reputation for dependability and quality work is responsible for the growth in business. The family has decided it wants to continue to grow the business, but additional financing will be needed in order to accomplish that goal. The company will use the financing, in part, to purchase additional equipment and hire more employees. JCCC management expects that this will enable a 15 percent per year growth in contract revenue and gross receipts over the next five years. Until now, the company has been financed solely through capital invested by the family and the profits from operations. The company's bookkeeper has maintained records of the contracts and billings, as well as all other necessary information for tax and business purposes. There has been no need in the past for external reporting with financial statements based on Generally Accepted Accounting Principles (GAAP). However, the bank that will be issuing the new loan to the company is requiring submission of GAAP financial statements along with a compilation report from a CPA firm. An audit will not be required at this time.

The company has maintained its records on the accrual basis and uses the completed contract method of accounting for its contracts. Although it is a family owned business, it files returns and pays taxes as a corporation. The company has hired your CPA firm to compile comparative financial statements for the years ended December 31, 2006 and 2005 and also to prepare its 2006 corporate tax returns. In addition, Joe Carpenter, Chief Operating Officer, and Jill Aspen, bookkeeper, have asked that you educate them about any significant tax and financial reporting issues that the company faces and what impact the company's projected growth may have on its tax and financial situation.

As with all construction companies, one of the biggest issues for both tax and financial reporting purposes is the proper revenue recognition on the construction contracts. At your firm's request, Jill Aspen has downloaded the company's ledger information for uploading into your firm's automated work paper system. In addition, she has sent the following information about the company's contracts for 2005 and 2006. In some cases, final contract prices differ from the original prices due to change orders approved by both JCCC and its customer. Change orders are contract modifications for work or materials not included in the original plan.

As this information illustrates, the company's contract volume is increasing. According to Jill, the company has grown every year since its inception, although the growth in the last year has leveled off due to capacity constraints (Gross receipts from all contracts were $\$ 7,102,000$ million in 2003, $\$ 9,502,350$ in 2004, $\$ 10,950,722$ in 2005 and $\$ 11,187,131$ in 2006). JCCC's contracts represent medium-sized projects that are completed within a two-year time frame. Joe prides himself on how well his final job profits align with his initial bid estimates. The company very rarely has unexpected unbillable cost overruns. Despite its success, the company maintains a very modest office space in order to keep administrative overhead low. 


\begin{tabular}{|c|c|c|c|c|c|c|}
\hline \multicolumn{7}{|c|}{ December 31, 2006 Work in Progress } \\
\hline $\begin{array}{l}\text { Contract } \\
\text { Number }\end{array}$ & $\begin{array}{c}\text { Contract } \\
\text { Price }\end{array}$ & $\begin{array}{c}\text { Costs } \\
\text { Incurred to } \\
\text { Date }\end{array}$ & $\begin{array}{c}\text { Estimated } \\
\text { Costs Left to } \\
\text { Complete }\end{array}$ & $\begin{array}{c}\text { Total } \\
\text { Estimated } \\
\text { Costs at } \\
\text { Completion }\end{array}$ & $\begin{array}{c}\text { Billings to } \\
\text { Date }\end{array}$ & $\begin{array}{c}\text { Collections } \\
\text { Received to } \\
\text { Date in } 2006\end{array}$ \\
\hline 1531 & $\$ 1,463,905$ & $\$ 1,124,235$ & $\$ 25,320$ & $\$ 1,149,555$ & $\$ 1,200,000$ & $\$ 1,200,000$ \\
\hline 1533 & $\$ 624,819$ & $\$ 450,382$ & $\$ 40,593$ & $\$ 490,975$ & $\$ 600,000$ & $\$ 550,000$ \\
\hline 1534 & $\$ 2,190,395$ & $\$ 1,646,900$ & $\$ 21,400$ & $\$ 1,668,300$ & $\$ 2,000,000$ & $\$ 2,000,000$ \\
\hline 1535 & $\$ 1,573,000$ & $\$ 1,211,523$ & $\$ 52,395$ & $\$ 1,263,918$ & $\$ 1,200,000$ & $\$ 1,000,000$ \\
\hline 1536 & $\$ 925,000$ & $\$ 628,933$ & $\$ 102,384$ & $\$ 731,317$ & $\$ 700,000$ & $\$ 625,000$ \\
\hline 1537 & $\$ 640,300$ & $\$ 450,250$ & $\$ 72,049$ & $\$ 522,299$ & $\$ 500,000$ & $\$ 500,000$ \\
\hline 1538 & $\$ 550,000$ & $\$ 421,392$ & $\$ 1,500$ & $\$ 422,892$ & $\$ 400,000$ & $\$ 350,000$ \\
\hline 1539 & $\$ 1,200,000$ & $\$ 940,596$ & $\$ 40,392$ & $\$ 980,988$ & $\$ 940,500$ & $\$ 900,000$ \\
\hline 1540 & $\$ 164,900$ & $\$ 112,059$ & $\$ 14,302$ & $\$ 126,361$ & $\$ 100,000$ & $\$ 75,000$ \\
\hline 1541 & $\$ 750,835$ & $\$ 321,405$ & $\$ 259,380$ & $\$ 580,785$ & $\$ 300,000$ & $\$ 300,000$ \\
\hline 1542 & $\$ 376,450$ & $\$ 43,500$ & $\$ 240,029$ & $\$ 283,529$ & $\$ 37,645$ & $\$ 37,645$ \\
\hline 1543 & $\$ 2,810,400$ & $\$ 426,049$ & $\$ 1,392,049$ & $\$ 1,818,098$ & $\$ 300,000$ & $\$ 0$ \\
\hline
\end{tabular}

\begin{tabular}{|c|c|c|c|}
\hline \multicolumn{4}{|c|}{ Contracts Completed in 2005 } \\
\hline Contract Number & Contract Price & Total Costs & Cash Collected in 2005 \\
\hline 1512 & $\$ 859,403$ & $\$ 633,085$ & $\$ 500,000$ \\
\hline 1513 & $\$ 1,003,958$ & $\$ 890,384$ & $\$ 750,000$ \\
\hline 1514 & $\$ 2,294,803$ & $\$ 1,920,938$ & $\$ 75,000$ \\
\hline 1515 & $\$ 684,950$ & $\$ 510,938$ & $\$ 93,094$ \\
\hline 1517 & $\$ 694,865$ & $\$ 573,849$ & $\$ 53,948$ \\
\hline 1518 & $\$ 194,803$ & $\$ 139,485$ & $\$ 495,083$ \\
\hline 1519 & $\$ 1,220,948$ & $\$ 948,509$ & $\$ 485,903$ \\
\hline 1520 & $\$ 984,095$ & $\$ 709,580$ & Cash Collected in 2006 \\
\hline & \multicolumn{1}{|c|}{ Contracts Completed in 2006 } & $\$ 37,250$ \\
\hline Contract Number & Contract Price & Total Costs & $\$ 139,670$ \\
\hline 1521 & $\$ 162,250$ & $\$ 120,593$ & $\$ 339,555$ \\
\hline 1522 & $\$ 539,670$ & $\$ 494,209$ & $\$ 200,600$ \\
\hline 1523 & $\$ 1,039,555$ & $\$ 790,205$ & $\$ 465,000$ \\
\hline 1524 & $\$ 875,600$ & $\$ 630,294$ & $\$ 136,750$ \\
\hline 1525 & $\$ 2,465,000$ & $\$ 2,042,039$ & $\$ 2900,000$ \\
\hline 1526 & $\$ 436,750$ & $\$ 1,325,904$ & $\$ 579,422$ \\
\hline 1527 & $\$ 1,900,000$ & $\$ 532,058$ & $\$ 294,805$ \\
\hline 1528 & $\$ 729,422$ & $\$ 204,938$ & $\$ 183,974$ \\
\hline 1529 & $\$ 294,805$ & $\$ 129,038$ & \\
\hline 1530 & $\$ 183,974$ & & \\
\hline
\end{tabular}

Jill feels as though she has the company's books in good order, but has some specific questions she would like you to address. She is concerned that the company may have to report income on its contracts under the percentage of completion method for the financial statements. Although she is vaguely familiar with the method, she is not certain if it applies to JCCC. She would also like confirmation that the completed contract method should be used for tax purposes. She heard something at a tax seminar about "look back" rules for long-term contract revenue recognition, but she does not know if those rules apply to JCCC. She has asked you to write her a letter answering the following questions. She would like you to include references to the appropriate financial reporting standards and tax authority so that she has that information for her records.

Another accounting issue raised by Jill is that she is unsure how to report the investments that JCCC had. Joe Carpenter had inherited a large sum of money from his parents, which he invested in the business. Until now, the company had plenty of idle cash, which is unusual for construction contractors, and it had invested the unneeded 
funds in stocks of other companies. However, the company's growth and need for more cash have prompted the selling of all of the stock. None of the investments represents greater than a 2 percent ownership interest in the investee. Jill has provided you with the following information about the stock transactions.

\begin{tabular}{|c|c|c|c|c|c|c|c|}
\hline \multicolumn{2}{|c|}{ JCCC Stock Investments Transaction Data } \\
\hline Description & $\begin{array}{c}\text { Number of } \\
\text { Shares }\end{array}$ & $\begin{array}{c}\text { Date } \\
\text { Purchased }\end{array}$ & Date Sold & $\begin{array}{c}\text { Purchase } \\
\text { Price Per } \\
\text { Share }\end{array}$ & $\begin{array}{c}\text { Sales Price } \\
\text { Per Share }\end{array}$ & $\begin{array}{c}\text { Market } \\
\text { Price per } \\
\text { Share on } \\
\mathbf{1 2 / 3 1 / 0 5}\end{array}$ & $\begin{array}{c}\text { Market } \\
\text { Price per } \\
\text { Share on } \\
\mathbf{1 2 / 3 1 / 0 6}\end{array}$ \\
\hline $\begin{array}{c}\text { Mankato } \\
\text { Manufacturing Corp }\end{array}$ & 2000 & $3 / 20 / 1997$ & $1 / 15 / 2007$ & $\$ 25$ & $\$ 24$ & $\$ 32$ & $\$ 22$ \\
\hline $\begin{array}{c}\text { Twin Cities Metals, } \\
\text { Inc. }\end{array}$ & 500 & $5 / 15 / 1997$ & $1 / 18 / 2007$ & $\$ 40$ & $\$ 52$ & $\$ 46$ & $\$ 52$ \\
\hline $\begin{array}{c}\text { Four M Chemical } \\
\text { Corp. }\end{array}$ & 750 & $4 / 01 / 1998$ & $1 / 25 / 2007$ & $\$ 32$ & $\$ 57$ & $\$ 52$ & $\$ 55$ \\
\hline Wobegon Brands, Inc & 625 & $12 / 15 / 1998$ & $2 / 1 / 2007$ & $\$ 28$ & $\$ 25$ & $\$ 35$ & $\$ 29$ \\
\hline
\end{tabular}

Your supervisor has looked over information provided by JCCC and has some additional concerns. JCCC has been using QuickBooks Premier Contractor edition, which has been fine in the past. However, your boss is concerned that as JCCC grows, its current accounting system may prove inadequate. She wants to show JCCC's owners that your firm can add value to their business by offering business improvement suggestions. She would like you to research alternative software solutions that might better meet the company's needs in the future. In addition, she thinks that JCCC and its owners might save a great deal of money by electing S-Corporation status for tax purposes, and would like you to look into the issue. A meeting has been set with the client in two weeks to discuss the accounting and tax issues, but your boss would like to send a letter to the client before the meeting addressing the S-Corporation and software ideas if there are solid recommendations to be made.

\section{Questions}

1. Prepare an internal document for the CPA firm's files to address the issues raised in items a through d. Be sure to include specific citations to the relevant authorities and adequately support all recommendations made.

a. For financial reporting purposes, should the company currently be using the completed contract method for contract revenue recognition, or the percentage of completion method? Identify the circumstances under which each of the two methods would be acceptable and explain why JCCC should or must use the method you are recommending.

b. For income tax purposes, should the company currently be using the completed contract method for contract revenue recognition, or the percentage of completion method? Identify the circumstances under which each of the two methods would be acceptable and explain why JCCC should or must use the method you are recommending.

c. What is the "look back" requirement for tax purposes and does it apply to JCCC? Under what circumstances would it apply?

d. How should the company's investments be reported on its 2005 and 2006 balance sheets (i.e. classification and dollar amount)?

2. Write a letter to JCCC's management addressing the following:

a. Identify some additional accounting software products that JCCC might find more suitable in the future and describe their benefits or drawbacks in comparison with QuickBooks.

b. Briefly explain to Joe and the other executives what an S Corporation is. Discuss whether or not JCCC would qualify for S-Corporation status for tax purposes and why it might be advantageous for JCCC to elect to be treated as an S-Corporation. 


\section{Teaching Notes}

This case requires students to research both financial reporting standards and authoritative tax sources to answer questions commonly faced in the construction industry. This case was not based on an actual company, but rather was created based on the author's experience with the construction industry in general. While the case can be completed as an individual assignment or as a group activity, the use of groups is recommended. The case should take a total of 10 to 15 hours to complete in its entirety. It was designed for use in a capstone accounting course to demonstrate the impact of business activities on both tax reporting and financial statements.

Instructors have the option to choose only the tax-related issues if using the case in a tax course or use only the financial reporting questions in an intermediate accounting course. By having the students prepare both an internal document for the CPA firm's files and a letter to the client, the students are forced to consider the audience they are writing for and adjust the language accordingly. This can lead to a useful discussion about the level of detail and technical information required for the firm's internal documentation as compared to the need to communicate effectively to a non-accountant client.

\section{Suggested Solutions:}

1. The students' internal memos should include specific citations to the authoritative literature and provide logical arguments for the recommendations made. Key sources and conclusions are summarized below.

a) For financial reporting purposes, should the company currently be using the completed contract method for contract revenue recognition, or the percentage of completion method? Identify the circumstances under which each of the two methods would be acceptable and explain why JCCC should or must use the method you are recommending.

JCCC should use the Percentage of Completion method. ARB No. 45 and Statement of Position 81-1 (SOP 81-1) provide guidance for the accounting for long-term construction contracts. Both establish a clear preference for using the percentage-of-completion method (PCM). Per SOP 81-1, for the PCM to be used, the following conditions must be met:

i) the contract should include language that clearly identifies enforceable rights in regard to the goods to be delivered or services to be performed,

ii) the contractor should be reasonably sure that the customer will satisfy all obligations under the contract

iii) the contractor intends to perform its obligations under the contract,

iv) the contractor must be able to reasonably estimate the costs to complete contracts and determine the extent of contract completion

In other words, if JCCC's contracts have a known and realizable sales price and the company can adequately estimate its contract costs and percentage complete on contracts, then it should use the PCM. If those requirements are not met, the completed contract method must be used. SOP 81-1 also indicates that the completed contract method could be used if the results would not be materially different than PCM. JCCC has known and realizable contract prices and has a history of accurate cost estimation. Therefore, it should use the PCM for its financial reporting purposes.

Other relevant sources: Financial Accounting concepts No. 5 paragraph 84 item c and ARB No. 45

b) For income tax purposes, should the company currently be using the completed contract method for contract revenue recognition, or the percentage of completion method? Identify the circumstances under which each of the two methods would be acceptable and explain why JCCC should or must use the method you are recommending.

JCCC can use the completed contract method for 2006, but will be required to use the percentage of 
completion method for 2007. IRC $\S 460(f)(1)$ defines a long-term contract as "any contract for the manufacture, building, installation, or construction of property if such contract is not completed within the taxable year in which such contract is entered into." Per review of JCCC's contract schedules, most contracts span two tax years. Therefore, treatment as long-term contracts is appropriate.

Under IRC $\S 460(b)(1)$, taxpayers must use the percentage of completion method to report taxable income from long-term contracts, subject to certain exceptions. The degree of completion is generally determined by comparing the total allocated contract costs incurred to date with the total estimated contract costs, otherwise known as the "cost-to-cost method." Two exceptions to this requirement are described in IRC $\S 460(\mathrm{e})$. The first exception is for any home construction contract (defined in IRC $\S 460(\mathrm{e})(6)(\mathrm{A})$ ) entered into after June 20, 1988. Since JCCC does no home construction, none of its contracts would meet this exception. The second exception is for small construction contractors, as defined in IRC $\S 460(\mathrm{e}) 1)(\mathrm{B})$. Contracts meet this exception if, when the contract was entered into, the company estimated that the contract would be completed within two years from the date the contract began, and if the contractor's average annual taxable gross receipts for the three prior tax years were less than or equal to $\$ 10$ million. As stated in the case, all of JCCC's contracts are normally completed within a twoyear time frame. JCCC's average gross receipts for 2003, 2004, and 2005 are $\$ 9,185,024$. This is less than $\$ 10$ million, so that exception is met for tax year 2006. However, the average gross receipts for 2004, 2005, and 2006 are $\$ 10,546,734$. Because of JCCC's growth, it will be required to switch to the percentage of completion method for tax year 2007. During this converting year, any contracts previously in progress are still accounted for under the method the company has been using (completed contract method). Any new contracts started are computed on the percentage of completion method. This is known as the "cut-off" method. Because switching to PCM is a statutory change, the change in accounting method procedures (i.e., filing Form 3115) do not apply.

\section{c) What is the "look back" requirement for tax purposes and does it apply to JCCC?}

JCCC would not be subject to the look-back provisions for 2006 if it continues to use the completed contract method for tax purposes. However, it will have to apply the look-back provisions in 2007 when it switches to the PCM.

The look back provision is basically a mechanism to determine if a contractor's estimates in using percentage of completion accounting have caused taxes to be underpaid or overpaid in prior years. IRC $\S 460(b)(2)$ provides that, in the taxable year in which a contract is completed, the company must calculate whether or not the taxes paid in regard to that contract in prior years were more or less than the amount that would have been paid if the actual cost and contract price, rather than estimated contract price and cost, had been used to compute taxable income. If tax was overpaid or underpaid based on the actual contract results, the taxpayer must calculate interest due on underpayments and interest owed to the taxpayer on overpayments. There is no change in the total tax due, just interest for the timing errors in the payment of the tax. The company will have to file Form 8697, Interest Computation Under the Look-Back Method for Completed Long-Term Contracts, in any tax year in which a contract subject to the look-back method is completed.

d) How should the company's investments be reported on its 2005 and 2006 balance sheet (i.e. classification and valuation)?

FASB No. 115 paragraph 12 indicates that equity securities with easily determined market values should be classified as either trading securities or available for sale securities. Trading securities are securities bought by the company with the purpose of resale in the short term and, therefore, are always classified as current assets. Available for Sale securities are securities that are not either trading securities or held to maturity securities. Available for sale securities can be either current or long term. JCCC purchased all its securities for long-term investment, not for resale. Therefore, they should be classified as Available for Sale securities. Per ARB 43 Chapter 3A, current assets are those expected to be converted into cash within one year. Therefore, one could make an argument that at December 31, 2005, the investments should be classified as long term, but at December 31, 2006 they should be classified as short term. Students might argue that the securities should be moved to trading securities, since management decided to sell them, but this practice is discouraged. 
The securities should be reported at their fair market values and the unrealized gains or losses should be reported in stockholders' equity as part of comprehensive income, not as part of net income. For JCCC, the balances reported would be:

\begin{tabular}{|c|c|c|c|c|c|c|}
\hline & $\begin{array}{c}\text { Number of } \\
\text { Shares }\end{array}$ & Market Value & Market Value & Balance & Balance & $\begin{array}{c}\text { 2006 } \\
\text { unrealized } \\
\text { Gain (Loss) }\end{array}$ \\
\hline MMC & 2000 & $12 / 31 / 2005$ & $12 / 31 / 2006$ & $12 / 31 / 2005$ & $12 / 31 / 2006$ & \\
\hline TCM & 500 & $\$ 32$ & $\$ 22$ & $\$ 64,000$ & $\$ 46,000$ & $(\$ 20,000)$ \\
\hline 4M & 750 & $\$ 52$ & $\$ 52$ & $\$ 23,000$ & $\$ 26,000$ & $\$ 3,000$ \\
\hline Wobegon & 625 & $\$ 35$ & $\$ 55$ & $\$ 39,000$ & $\$ 41,250$ & $\$ 2,250$ \\
\hline
\end{tabular}

2. The letter should be properly formatted. Students should use their creativity in assigning an address to the client. The instructor may wish to provide the students with a suggested format ahead of time. Students tend to have difficulty adjusting the language to be appropriate for a non-technical audience. They should be encouraged to summarize their recommendations without using technical jargon or quotations from the Internal Revenue Code.

a. Identify some additional accounting software products that JCCC might find more suitable in the future and describe their benefits or drawbacks in comparison with QuickBooks.

Any reasonable answer should be acceptable here. For whatever products the students choose to examine, they should clearly describe the features and why the products would or would not be an improvement over QuickBooks. In reality, a CPA firm would not include any products in the letter that would not be recommended as improvements to QuickBooks, because the purpose of the letter is to make useful recommendations. The client has not requested this information.

b. Briefly explain to Joe and the other executives what an S Corporation is. Would JCCC qualify for SCorporation status for tax purposes? If so, do you think it might be advantageous for JCCC to apply for $S$ Corp status? Why or why not?

Yes, JCCC could elect S-corporation status. An "S" Corporation is recognized by the IRS as a passthrough entity for tax purposes. Generally, this election was intended to be a benefit for smaller businesses. The company must meet the requirements established in the Internal Revenue Code and must file an election to be treated as an S-corporation. The requirements are specified in $\S 1361$. An eligible corporation can have no more than 100 shareholders. These shareholders must be individuals who are not nonresident aliens (or certain trusts). The company can only have one class of stock. JCCC appears to meet all of these requirements.

Students should describe the potential advantages to the client. It may be advantageous because the owners could avoid double taxation on the company's income. The company would be taxed on the owners' returns and not on the company's returns. This is generally an advantage when the company is profitable, as is the case with JCCC. 